4.Державна служба статистики України. URL: http://www.ukrstat.gov.ua/druk/soc_ek/2018/publ_12_2018_u.html

5. Жаровська Г.П. Способи мінімізації ризиків кримінальної діяльності суб'єктами транснаціональної організованої злочинності. Вісник Запорізького національного університету. Юридичні науки. 2015. № 2 (I). С. 179-186.

6. Новікова Л.В. Глобалізація та транснаціональна економічна злочинність: питання сьогодення. Право і Безпека. 2010. № 3. С. 26-30.

7. Падалка А.М. Концептуальные основы противодействия организованной преступности в налоговой сфере. Международный научно-практический правовой журнал (LEGEA SI VIATA). 2018. Вып. 10/2. С. 73-76.

8. Полянська В.С. Питання європейського співробітництва у протидії транснаціональній організованій економічній злочинності. Науковий вісник Національної академії внутрішніх справ. 2018. № 3 (108). С. 67-79.

9. Конвенція Організації Об’єднаних Націй проти транснаціональної організованої злочинності : прийнята резолюцією 55/25 Генеральної Асамблеї від 15.11.2000 p. URL: http://zakon3.rada.gov.ua/laws/show/995_789.

UDC 383.351

DOIhttps://doi.org/10.32782/2524-0374/2019-4/52

\title{
PROPHYLAXIS AND PREVENTION OF RESIDENTIAL BURGLARIES
}

\section{ПРОФІЛАКТИКА ТА ЗАПОБІГАННЯ ЖИТЛОВИХ КРАДІЖОК}

\author{
Vasilenko N.D., Doctor of Law Sciences, \\ Head of the department of Cybersecurity \\ National University "Odesa Law Academy"
}

Loginova N.I., PHD in Pedagogikal Sciences, Head of the department of Information technologies National University "Odesa Law Academy"

Kozin O.B., PhD in Physico-mathematical Sciences Associate Professor of the department of Cybersecurity National University "Odesa Law Academy”

It is well known that among property crimes thefts always prevail. Recently, the problem of combating thefts with penetration into the dwelling, referred to as apartment thefts, has acquired particular urgency. The prevalence of burglaries, as well as the high level of crime in general, are a consequence of the imperfection of social relations, the unstable political situation in the country, and the deterioration of the economic situation. The causes and conditions (factors) that give rise to burglaries and facilitate their commission are complicated and complex. This implies an equally complex and multilevel character of preventive and prophylactic activities aimed at eliminating and neutralizing criminogenic factors. The proposed article highlights the results of our study of the special literature and apartment anti-theft practices in Ukraine, and gives recommendations on how to prevent such thefts. This article provides a criminological characteristic of burglaries by place, time, setting, methods of committing them. Special factors are also noted. There are conditions that directly contribute to the commission of thefts from apartments. Causes, methods, and other circumstances of the committion of burglaries are analyzed. Also we analyzed the features of the implementation of practical organizational, preventive, technical and legislative measures, for search the ways to improve ways of dealing with burglary at the modern stage. The priority areas to improve the disclosure of the appartment thefts are indicated, including the creation of an effective system of prophylactic measures, operational search and material, logistical, informational and consultative support in the activities of law enforcement agencies. Based on the results obtained, scientific recommendations to prevent or reduce apartment theft and increase the disclosure of this type of crime were formulated. Proposals for amendments to the Criminal Code of Ukraine in the direction of increasing responsibility for theft, combined with the penetration of housing were also formulated.

Key words: residential burglary, apartment thefts, preventive and prophylactic activities, criminological characteristic, crime prevention, measures to protect against burglaries.

Загальновідомо, що серед майнових злочинів завжди переважають крадіжки. Останнім часом особливої актуальності набула проблема боротьби з крадіжками з проникненням у житло, звана квартирними крадіжками. У пропонованій статті висвітлюються підсумки дослідження авторами спеціальної літератури, офіційних інтернет-джерел Генеральної прокуратури України, Прокуратури Одеської області, практики боротьби з квартирними крадіжками в Україні. Автори цієї роботи спробували узагальнити досвід боротьби з цим видом злочинності і тенденції її розвитку. На підставі отриманих результатів були сформульовані наукові рекомендації щодо вдосконалення заходів із попередження, зменшення квартирних крадіжок, із підвищення ефективності застосування кримінального законодавства і збільшення розкриваності цього виду злочинів.

У статті зазначено, що поширеність крадіжок зі зломом, а також високий рівень злочинності загалом $є$ наслідком недосконалості суспільних відносин, нестабільної політичної ситуації в країні та погіршення економічної ситуації нині. Причини і умови (фактори), які викликають квартирні крадіжки і полегшують їх вчинення, є складними і комплексними. Тому пропонується і подається на розгляд багаторівневий характер попереджувально-профілактичних заходів, спрямованих на усунення та нейтралізацію криміногенних факторів. У роботі ця кримінологічна характеристика квартирних крадіжок за місцем, часом, обстановинами, способами їх здійснення. Зазначено і спеціальні чинники - умови, що безпосередньо сприяють вчиненню крадіжок із квартир. Проведено аналіз причин, способів і інших обставин вчинення квартирних крадіжок. Проаналізовано також особливості реалізації практичних організаційних, профілактичних, технічних і законодавчих заходів, із метою пошуку шляхів вдосконалення способів боротьби з квартирними крадіжками на сучасному етапі. Визначено пріоритетні напрями вдосконалення розкриття цього виду злочинів, у тому числі створення ефективної системи заходів профілактичного, оперативно-розшукового, матеріально-технічного, інформаційно-консультативного забезпечення в діяльності правоохоронних органів. У роботі також сформульовані пропозиції про внесення змін до КК України в бік посилення відповідальності за крадіжку, поєднану з проникненням у житло.

Ключові слова: квартирна крадіжка, кримінологічна характеристика, попереджувально-профрілактичні заходи, захист житла, профілактика злочину, комплексне кріминологічне дослідження. 
Residential burglaries (thefts from home or apartment thefts), occupies a significant place in the overall structure of crime. Lowering the standard of living of the population, unemployment, the weakness of social protection of the population and, as a consequence, an increase in the proportion of poor elements potentially prepared for committing crimes against property, the presence of refugees, the lack of funds necessary to protect objects from criminal encroachments, and others - this is not an exhaustive list of reasons that lead to the theft of someone else's property.

Thefts of property of citizens, especially thefts from home, have a particularly negative impact on the material condition of people, and affect the moral and psychological atmosphere in society. In case of thefts with penetration into the home, the inviolability of citizens' homes is also violated, guaranteed by Art. 30, 41 of the Constitution of Ukraine and the Criminal Code. Law enforcement agencies are making efforts to protect the rights of our citizens from this criminal activity. However, this is often not enough to prevent crime. Measures for the prevention of burglaries, to date, are not effective enough. Fighting burglaries can be based only on a real assessment of what is happening. Here it is necessary to answer a number of questions for the prevention of room thefts. First of all, it is necessary to try to understand what conditions are conducive to the commission of burglaries, why the efforts of state law enforcement and other agencies aimed at preventing burglaries do not give the expected effect?

At present, the fight against crime, including burglary, has become an important national task, the solution of which also helps to construct and strengthen of a democratic rule-of-law state. Widely known are the scientific works of foreign and Ukrainian scientists who were engaged in and engaged in research into the problems of burglaries in the field of criminal law. This is E.I. Makarenko, G.M. Borzenkov, B.M. Golovkin, O.O. Chernenko, O.L. Khlystun, S.V. Panova, V.V. Slyusar, A.V. Bryzhak, A.M. Nazarenko, R.S. Belkin, A.N. Vasilyeva, V.Yu. Shepitko, V.N. Fedorov, L.G. Vidonova, V.P. Kolmakova, V.P. Konovalova, V.I. Litvinova, Yu.I. Lyapunova, P.S. Matishevsky, A.A. Pinaev, P.M. Malanchuk, P.Ya. Minka O.G. Shvydkoy and others. In scientific publications, periodicals, the Internet $[4$, p. 7-12] given scientific reviews on issues about burglary. So, in [3, p. 269] the author notes the need for the work of the criminal investigation units to prevent burglaries using the forces and means of operational search activities It is noted, that preventive work should be aimed primarily at eliminating the causes and conditions that contribute to the commission of burglary. Thefts with penetration into the dwellings are analyzed in [4]. In [5. p. 134] investigated four lines of protection of residential buildings and premises from theft. The interaction of law enforcement agencies, municipal authorities, government organizations and the public is analyzed in article [6, p. 31]. In a scientific publication [11, p. 145] reviewed the criminological basis for the activities of criminal investigation officers in particular for the prevention of theft with home penetration. In scientific work [12], a systematic analysis of data on thefts related to the penetration into housing in Ukraine in general and, in the Odessa region in particular, is carried out. A set of practical organizational, preventive, technical and legislative methods and forms are proposed for their reduction or elimination. Apartment theft is characterized by a high level of "professionalism" of intruders, the presence of special skills and abilities, careful preparation for committing a crime [14, p. 11-14]. E.I. Makarenko shares the methods of penetrating thieves in a residential or other room into four groups, depending on the methods and means of such penetration. Each of these groups requires theft of special qualities: from masterful possession of means of hacking to outstanding artistic abilities. In this regard, this kind of crime is characterized by a sufficiently high number of previously convicted intruders.

The proposed work highlights the results of our study of the special literature and anti-burglary practices in Ukraine, and gives recommendations on how to prevent such thefts.
The purpose of this article is to: conducting an analysis of the causes, methods, and other circumstances of the commission of burglaries; analysis of the features of the implementation of a complex of practical organizational, preventive, technical and legislative measures;

conducting a search for ways to improve the methods of combating apartment thefts at the present stage;

formulation of scientific recommendations for reducing these types of crimes, increasing their disclosure and their prevention on the basis of the results obtained.

According to the Accounts Chamber of Ukraine, the poverty rate in Ukraine according to the non-monetary criterion in 2017 has increased to $27 \%$. Almost a third of Ukrainians cannot get prescribed medicines and medical supplies and pay for a doctor's services and treatment in a hospital without a surgical operation [13]. Such a trend, in the distribution of material goods and the high degree of polarization of the population by income levels generate social tension and spontaneous aspiration of the impoverished people of the masses, who have appeared in a state of forced criminal activity, to the most primitive illegal means of redistribution of property, including theft.

In the negative psychological processes taking place today in the Ukrainian society place a special place, in our opinion, the cultivation of the consumer system of social values, the general increase in the mercenary motivation of people's behavior, especially among those, who once broke the law. The moral pseudo-justification of any way of obtaining property wealth, the loss of confidence and willingness by most of the adult population to support law enforcement agencies involved in the investigation and disclosure of crimes, as well as the widespread spread of judgments about helplessness and of official negligence of investigative bodies, is increasing. All of this, of course, plays a significant criminal role.

According to statistics, apartment thefts are crimes that are most often committed against property. They, all by the same statistical data, often remain undisclosed. Therefore, any theft is easier to prevent than after looking for a stolen one.

The foregoing gives grounds to say that reasons, methods and other circumstances of committing apartment thefts, their causes and conditions, as well as measures of their prevention, need further study and coverage.

We will review the data presented on the official website of the General Prosecutor's Office of Ukraine [1] and analyze them.

Table 1

Number of apartment thefts committed in Ukraine in 2014 and 2018

\begin{tabular}{|c|c|c|}
\hline Year & $\begin{array}{c}\text { Number of apartment } \\
\text { thefts per year }\end{array}$ & $\begin{array}{c}\text { Number of apartment thefts } \\
\text { in which individuals were } \\
\text { notified of a suspicion }\end{array}$ \\
\hline 2014 & 18992 & 4763 \\
\hline 2018 & 20228 & 4597 \\
\hline
\end{tabular}

As can be seen from Table 1, in 2018, the number of apartment thefts committed in Ukraine increased from $6.5 \%$ in comparison with 2014, and the number of apartment thefts, in which individuals received a notification of suspicion, dropped by $3.5 \%$ compared to 2014 . We will analyzing the data on apartment thefts in the Odessa region, presented on the official website of the General Prosecutor's Office of Ukraine [2]. They are listed in Table 2.

Table 2

The number of apartment thefts committed in the Odessa region in 2014 and 2018

\begin{tabular}{|c|c|c|}
\hline Year & $\begin{array}{c}\text { Number of apartment } \\
\text { thefts per year }\end{array}$ & $\begin{array}{c}\text { Number of apartment thefts } \\
\text { in which individuals were } \\
\text { notified of a suspicion }\end{array}$ \\
\hline 2014 & 853 & 119 \\
\hline 2018 & 1888 & 113 \\
\hline
\end{tabular}


As can be seen from Table 2, the number of apartment thefts committed in the Odessa region, increased in 2018 by $121 \%$ compared with 2014 , and the number of apartment thefts, in which persons received a notification on suspicion in 2018, decreased by $4.7 \%$ in comparison with 2014 .

In the crime prevention system, two main elements - prevention and repression - should be distinguished. At the same time, the main role belongs, of course, to prevention, which represents a special type of social management, destined to ensure the safety of protected values.

It includes the development and implementation of targeted measures to identify, eliminate the causes and conditions conducive to the commission of crimes, as well as measures to provide a preventive effect on individuals, prone to their accomplishment. Since crime is a social phenomenon, its prevention should be based on the solution of, above all, general social problems. As long as there are general societal factors contributing to the crime, in particular, apartment thefts, only by means of special counter measures it is difficult to rely on serious success in the fight against crimes.

General social prevention of burglaries includes a wide range of socio-economic, political, legal, ideological, psychological, organizational and other measures aimed at developing the economy, stabilizing the political situation in the country, raising the material standard of living of the population, of culture and citizens' consciousness. And although these measures are not aimed directly at the prevention of burglaries, nevertheless, objectively counteracting common causes and conditions of crime, they create a favorable environment for the prevention of burglaries at a special criminological level. The most common place to commit theft with the penetration of housing is most often: apartments, houses owned by citizens on the right of personal property, hostels, etc.

The criminological characteristic of burglary involves the study of indicators such as the place, time, method of committing burglary; the type of apartments or houses from which thefts are being committed, the methods and channels for concealing and selling the stolen property.

The intensity of the theft of burglaries significantly depends on the time of year and month, but at the same time it depends on the time of day and days of the week. Most thefts occur in the morning and afternoon. According to the results of our research, the majority of burglaries are committed in a period of about 8 to 12 hours. By the day of the week, most of the thefts occur on weekdays (more than $90 \%$ ). On weekends and holidays their number drops sharply (less than 10\%).

The main methods of committing burglaries in major cities are the selection of the key to the front door lock and hacking entry doors. According to the results of our research, more than 40 to $45 \%$ of thefts were committed by selection of the key, and about the same number was done by hacking the entrance doors of apartments. Often used and the first (for opening the armored door) and the second (for opening the second - a wooden door).

We also immediately note special factors - conditions that directly contribute to the commission of thefts from apartments. These include: 1) the lack of technical measures to protect the home (apartment);2) the imperfection of the architecture of many houses; 3 ) careless attitude of individuals to their property; 4) the intensified process of accumulating wealth in individual apartments; 5) high population density in cities, anonymity of residence, a wide network of vehicles, allowing criminals to escape; 6) deficiencies in the activities of the internal affairs bodies engaged in the investigation and disclosure of burglary.

Victimological prophylaxis is associated with the provision by law enforcement agencies of a targeted impact on citizens in order to prevent them from creating favorable conditions for the actions of intruders. It consists mainly in carrying out wide explanatory work among the population by authorized employees of the internal affairs agencies by giv- ing speeches in the mass media, providing special advice to citizens, supplying them with reminders (warning about the dangers of burglary), reminding them that homeowners themselves should take security measures to ensure the safety of their property.

Prevention, carried out among the population, should not, in our opinion, be limited to the victimological aspect. It should also include the implementation of the following antitheft activities:

1) complex processing of the residential sector by the relevant internal affairs agencies when interacting with the public (according to our estimates, the effectiveness of this measure is more than $30 \%$; 2) the organization of regular reports on the preventive work of the internal affairs bodies in front of the population (efficiency - about 4\%); 3) involvement of the population in the work on the prevention of offenses, including burglaries, in residential neighborhoods by creating a network, for example, of urban (district) interconnected voluntary as well as unofficial police assistants (efficiency - more than $50 \%$ ).

A significant number of burglaries are committed in cities, urban settlements and especially in large cities with a population of one million or more people. In large cities, there is such a paradoxical situation in which, despite the high population density, people live mostly disconnected, in their absolute majority, without knowing each other's place of residence, which causes low social control (mutual control) in society. For these reasons, an unfavorable social and cultural situation is developing in large cities. All this causes a high level of crime, including the high number of burglaries.

Also important in the system of special measures according to their importance, we need to improve the technical means of protecting the apartments of citizens. Today, according to experts, the most reliable way to protect is centralized security of apartments.

The main enemies of the apartment thief are time and noise. Engineering and special tools create not only certain complexities of physical penetration, but also fight the burglary because of the noise they generate, as well as the time they take away from the thief. After your apartment is put on guard, the signal about each opening of the front door will come to the control panel of the non-departmental guard.

Besides the purposeful installation of the alarm system and the reduction of the cost of this service, it is also proposed to use loudspeaker negotiating devices connected with the dispatching station in the entrances of large residential houses; ubiquitous equipment of doors of entrances of multi-apartment houses with code locks with intercoms (intercoms); connection of apartments to centralized control panels at departments of non-departmental police guard; installation of apartments at lockers with high secrecy at the entrance doors, reinforcement of doors and door boxes, window retouching. This is an incomplete list of basic technical safety measures.

However, most often, apartment theft occurs during a long absence of hosts. If a citizen goes for a long time, it is better to put savings and values in a safe place - for example, in a bank cell.

In addition to the technical means of housing protection in the system of organizational and managerial measures for the prevention of apartment thefts, the following are also offered: 1) development of complex targeted programs to strengthen the fight against thefts committed from residential premises; 2) compilation of a data bank on the most common methods and methods of committing thefts with illegal entry into the home, as well as persons previously convicted of committing property crimes; 3 ) conducting extensive informative work among the population about the need to report any criminally significant information to the internal affairs authorities; 4) the study of European and world experience in the fight against apartment thefts. A separate topic is the relationship with the neighbors by the entrance. In the United States and many other European countries, community-based collaboration in 
housing protection has become more effective than policing. Everyone can independently show initiative in this direction. Keep in touch with the neighbors on your site, living below and above. Especially pay attention to people of retirement age. These people have a lot of free time; 5) the creation of a unified state system of information support, which allows to focus all types of operational records of internal affairs bodies involved in the investigation of apartment thefts.

The peculiarities and complexity of the disclosure of thefts also lie in the fact that sometimes the primary investigative actions are carried out poorly. For example, the review of the place of the event is carried out superficially, the data are not analyzed, the examination is not carried out. In practice, only the inspection of the place of incident and the removal of fingerprints of criminals, which do not lead to anything, because criminals have long been working in gloves for a long time. Unfortunately, for investigators there are no other technical means or methods for analyzing the crime scene. Therefore, it is proposed to improve the structure of the specialized (searchand-search) criminal investigation units, which include departments for combating thefts from apartments, by creating on their basis a single, scale-oriented city, oblast and state of the coordinating unit for combating apartment thefts, in connection with which it is also necessary:

provide additional, up-to-date resource facilities

To develop a special program for the training of junior prosecutor inspectors for the methodology for investigation and disclosure of apartment thefts;

to regulate the obligation of training on the specified program and internship of the younger prosecutor's inspectors prior to their approval in the position.

In our turn, among the measures of operative-search purpose, important means of preventing apartment thefts are, in our opinion, such as the constant monitoring by district police inspectors of the operational environment at the serviced areas. As for legislative measures aimed at preventing apartment thefts, it is necessary the following:

at first, systematization of the normative base for the organization of the fight against crimes against property; secondly, the normative regulation of the mechanism of compensation for damage caused to victims of property crimes; thirdly, the improvement of Part 3 of Art. 185 of the Criminal Code of Ukraine by means of a tightening of the sanction, which must be stated in the following wording: "is punishable by imprisonment for a term of three to eight years", fourthly, the development and adoption of a separate law on crime prevention for the gradual transition from a predominantly punitive model to combat mercenary crime, in which the latter is able to reproduce itself, to prophylactic

The prevalence of residential burglaries, as well as the high level of crime in general, are a consequence of the imperfection of social relations, the unstable political situation in the country, and the deterioration of the economic situation. The causes and conditions (factors) that give rise to burglaries and facilitate their commission are complicated and complex, which implies an equally complex and multilevel character of preventive and prophylactic activities aimed at eliminating and neutralizing criminogenic factors.

The work give an attempt was made to conduct a complex criminological study of apartment thefts, based on relevant data by Odessa and Ukraine. Work provides a criminological characteristic of residential burglaries by place, time, setting, methods of committing them. There are conditions that directly contribute to the commission of thefts from apartments. Special factors were also emphasized. In this work, sertain proposals were formulated to amend the Criminal Code of Ukraine in the direction of increasing responsibility for theft, coupled with the penetration of housing.

This paper makes scientific recommendations for improving measures to prevent burglaries. It is proposed to improve the structure of work for specialized (operational-search) subdivisions of the criminal investigation department, which include including the department on struggle against of the apartment thefts. Priorities for improving the disclosure of thefts are noted. They include the creation of an effective system of prophylactic measures, operational search, material, information, technical, advisory support in the activities of law enforcement agencies were emphasized.

For these purposes, the work proposes the implementation of a number of activities, including:

qualitative improvement of the material and technical base of the relevant departments of the internal affairs bodies, the introduction of new technologies in their activities for the detection of crimes;

orientation of secret police officers of the criminal investigation department to preferentially receive confidential information regarding the establishment of special criminogenic factors and the identification of persons prone to committing thefts from apartments, in order to provide them with timely preventive measures;

creation of permanent free access points for citizens for free consultation by civilian officials of the Ministry of Internal Affairs on all matters relating to burglary and countering this type of crime. Specific assistance in the selection of certain measures (means) of protection by the police, depending on the financial situation of the citizen;

study of European and world experience in the fight against theft. Including the collective interaction of neighbors in ensuring the safety of housing;

- development and adoption of a separate law on crime prevention for the gradual transition from a predominantly punitive model of combating crime to to preventive measures.

Theoretical conclusions and actual recommendations based on the work can be used by the bodies of the Ministry of Internal Affairs of Ukraine in developing the special events for the prevention of burglary, and also for investigating cases of burglary. Some provisions of the work can be used in the preparation of the new Criminal Code.

\section{REFERENCES}

1. General Prosecutor's Office of Ukraine. URL: http://www.gp.gov.ua/ua/stst2011.html?dir id=112661\&libid=100820\&c=edit\& c=fo

2. The Odessa Oblast Prosecutor's Office. URL: https://od.gp.gov.ua/ua/documents.html\#

3. Khlistun O.L. Activity of the units of the criminal investigation in preventing apartment thefts: operational-search aspect. Scientific Bulletin of the Lviv State University of Internal Affairs. 2014 No. 4. P. 263-274.

4. Panova S.V. Theft, moved with penetration into the home, as a phenomenon of social reality. Tribune of a doctoral student, postgraduate student, applicant. 2014. No. 27. P. 267-274.

5. Sliusar V.V. Victimologic prophylaxis of apartment thefts / V.V. Locksmith. Collection of scientific works on the materials of the round table. Kyiv, April 29, 2014. Kyiv : National. acad. inside cases, 2014. P. 133-135.

6. Chernenko O.O. Conducting preventive work by investigative departments of the ATS: problems and solutions. Scientific Bulletin of the Kherson State University. 2016. No. 2 (3). P. 29-31.

7. Nazarenko A.M. Victimity of victims of theft with penetration into the home, other premises or storage and measures to reduce its level. Collection of scientific works on the materials of the round table. Kyiv, April 29, 2014. Kyiv : National. acad. inside cases, 2014. P. 136-137.

8. Minka P.Ya. Problems of counteracting apartment thefts in modern conditions / P.Ya. Minka, Yu.V. Savitskaya. Scientific Bulletin of the Dnepropetrovsk State University of Internal Affairs : a collection of scientific works. 2007. № 2. P. 304-310.

9. Quick O.G. Prophylaxis and stopping of crimes connected with apartment thefts. Problems of law and law-enforcement activity: a collection of scientific works. 2005. No. 1. P. 192-200. 
10.Criminology. Educational and methodical manual / V.M. Dryomin, Zh.V. Mandrichenko, T.V. Melnichuk, Yu.O. Strelkovsky, A.I. Marchuk, A.M. Izovita, S.A. Ilko, N.O. Fedchun, V.Ya. Zitryak. Odessa : National University "Odessa Law Academy", 2015. 144 p.

11. Brzhak A.V. Prevention of employees of the units of the criminal investigation of theft, combined with the penetration into the home. The Bulletin of the Chernivtsi Faculty of the National University "Odessa Law Academy". 2015. № 2. P. 136-151.

12.Fedorov V.M. Residential burglary as a system of social reality / V.M. Fedorov, O.B. Kozin, O.B. Papkovskaya. Electronic scientific publication "Legal scientific electronic journal". 2017. № 6. P. 325-327. URL: http://lsej.org.ua/6_2017/96.pdf

13. In the situation of poverty in Ukraine, there have been positive developments, while the poverty level according to the non-monetary criterion in 2017 has increased to 27\% - the Accounting Chamber. URL: http://www.ac-rada.gov.ua/control/main/uk/publish/article/16757361.

14. Makarenko Ye.I. Investigation of crimes against private property of citizens. Textbook. Dnipropetrovsk : Dnepropetrovsk Humanitarian University, 2012. 107 p.

УДК 343.352

DOIhttps://doi.org/10.32782/2524-0374/2019-4/53

\title{
ОСОБЛИВОСТІ СТАНОВЛЕННЯ КРИМІНАЛЬНО-ПРАВОВОЇ СИСТЕМИ ПРОТИДІї КОРУПЦЇ̈ В УКРАЇНІ
}

\author{
SPECIAL ASPECTS OF EVOLVEMENT OF CRIMINAL LEGAL SYSTEM \\ FOR COMBATING CORRUPTION IN UKRAINE
}

Довженко Я.М., магістр права, молодий науковець

Статтю присвячено дослідженню проблеми становлення системи кримінально-правових заходів протидії корупції в Україні. Дослідження цього питання дало змогу визначити основні етапи становлення і розвитку нормативно-правової бази протидії корупції та особливості формування антикорупційного законодавства та системи протидії корупції в Україні. Етапи становлення і розвиток нормативно-правової бази протидії корупційній злочинності в Україні варто розглядати в контексті імплементації Україною міжнародних та європейських договорів у національному законодавстві.

За період незалежності Україна пройшла значний шлях становлення кримінального законодавства з протидії корупції. До національного законодавства в основному було імплементовано положення і рекомендації Конвенції Організації Об'єднаних Націй проти корупції 31 жовтня 2003 р., Кримінальної конвенції Ради Європи про боротьбу проти корупції від 21 січня 1999 р., Цивільної Конвенції Ради Європи про боротьбу з корупцією від 4 листопада 1999 р. та інші міжнародні акти з питань протидії корупції.

Зазначається, що в Кримінальному кодексі України не дається визначення поняття корупційного злочину. Натомість у примітці до ст. 45 Кримінального кодексу України дається перелік корупційних злочинів. Але такий перелік не є вичерпним. Як показує дослідження, цей перелік корупційних злочинів, зазначених у примітці до ст. 45 Кримінального кодексу, є неповним. Аналіз співвідношення національної та міжнародної систем корупційних злочинів свідчить, що вони повністю не збігаються. До корупційних не зараховані ряд злочинів, які міжнародними актами визнані корупційними. Водночас до корупційних належить низка злочинів, які міжнародними актами не зараховані до корупційних. Саме на цих особливостях акцентовано у проведеному дослідженні. Тому дійова протидія корупції в Україні можлива лише за умови прийняття досконалого законодавства та узгодження переліку корупційних злочинів з міжнародними стандартами.

Ключові слова: корупція, корупційна злочинність, протидія корупції, система протидії корупції, антикорупційне законодавство.

This article is dedicated to the problems of evolvement of the system of criminal legal measures aimed at combating corruption in Ukraine. The study of this issue made possible identification of the main stages of evolvement and development of the legal and regulatory framework for combating corruption and the special aspects of formation of anti-corruption legislation and anti-corruption system in Ukraine. The stages of evolvement and development of the legal framework for combating corruption in Ukraine should be considered in the context of implementation by Ukraine of international and European treaties in national legislation.

During the period of independence, Ukraine has come a long way of evolvement of criminal legislation against corruption. The provisions and the recommendations of the United Nations Convention against Corruption of October 31, 2003, the Council of Europe Criminal Law Convention on Corruption of January 21, 1999, the Council of Europe Civil Law Convention on Corruption of November 04, 1999 and other international acts on combating corruption were implemented to the national legislation.

It is noted, that the Criminal Code of Ukraine does not contain the concept of a corruption-related crime. In return, an addendum to article 45 of the Criminal Code of Ukraine provides a list of corruption-related crimes. However, such list is not comprehensive. The research shows that the list of corruption-related crimes mentioned in the addendum to article 45 of the Criminal Code is incomplete. The analysis of the correlation between the national and the international systems of corruption-related crimes shows that they do not coincide completely. A number of crimes that are recognized as corruption-related by international regulations are not included into corruption-related crimes in Ukraine. At the same time, a number of crimes that are not classified as corruption-related ones by international regulations are treated as such by Ukrainian law. These special aspects are on the focus of the made research. Therefore, the effective fight against corruption in Ukraine is possible only if perfect legislation is adopted and the list of corruption-related crimes is brought to compliance with the international standards.

Key words: corruption, corruption-related crimes, combating corruption, anti-corruption system, anti-corruption legislation.

Корупція є однією з найактуальніших соціальних проблем сучасності. Це повною мірою стосується України, високий рівень корумпованості якої визнано вітчизняними та зарубіжними аналітиками, відповідними міжнародними інституціями.

Запобігання та протидія корупції становлять одну 3 найбільш актуальних проблем, що постають у процесі проведення реформ в Україні. Корупція як негативне явище вимагає посилення ролі держави щодо протидії їй.
Мета статті полягає в дослідженні етапів та особливостей кримінально-правової системи протидії корупції в України, виявленні ії особливостей та недоліків.

Досвід запобігання та протидії корупції в Україні свідчить, що «підгрунтям цієї діяльності є іії нормативно-правове регулювання в межах євроінтеграційного процесу. Діалог між Україною та Європейським Союзом (ЄС) розпочався 14 червня 1994 р., коли було підписано Угоду про партнерство і співробітництво [7, с. 3]. Україна взяла на 